\title{
OBESITAS TERHADAP HARGA DIRI REMAJA
}

\author{
Sumiyati ${ }^{1}$, Dhian Irianti $^{2}$ \\ ${ }^{1}$ Poltekkes Kemenkes Semarang \\ ${ }^{2}$ Puskesmas Pagentan Dinkes Kabupaten Banjarnegara \\ email:007sumiyati@poltekkes-smg.ac.id
}

Riwayat Artikel: Diterima: 9 November 2021, direvisi: 25 November 2021, dipublikasi: 29 November 2021

\begin{abstract}
Obesity has an unfavorable impact on adolescent health and psychology. One of the bad effects of obesity on health is the risk of experiencing chronic diseases including heart disease, diabetes mellitus and cancer. Other effects of obesity in adolescents include impaired self-esteem. Self-esteem is a person's assessment of oneself, based on the suitability of one's behavior towards the ideal self. A person with a low level of self-esteem is caused by a large difference between self-concept and ideal self. The purpose of the study was to determine the relationship between obesity and adolescent self-esteem.

This type of research is an analytic survey with a cross sectional design. Sampling with a total sampling of 38 people in SMP Negeri 2 Pagentan. The research instrument used in this study has been tested for validity and reliability. The results of the study there is a relationship between obesity and self-esteem in adolescents with a $p$ value of 0.031 . It is recommended that health workers provide health education about self-esteem for adolescents who have obesity. Adolescents are expected to consume healthy food and balanced nutrition and perform regular physical activity.
\end{abstract}

Keywords: obesity; self esteem; adolescent

\begin{abstract}
ABSTRAK
Obesitas mempunyai dampak yang kurang baik pada kesehatan dan psikologis remaja. Salah satu dampak buruk obesitas bagi kesehatan adalah risiko mengalami penyakit kronis antara lain penyakit jantung, diabetes mellitus dan kanker. Efek lain dari obesitas pada remaja termasuk gangguan harga diri. Harga diri adalah penilaian seseorang terhadap diri sendiri, berdasarkan kesesuaian perilaku seseorang terhadap diri yang ideal. Seseorang dengan tingkat harga diri yang rendah disebabkan oleh perbedaan yang besar antara konsep diri dan diri ideal. Tujuan penelitian mengetahui hubungan obestitas denga harga diri remaja. Jenis penelitian ini survey analitik dengan rancangan cross sectional. Pengambilan sampel dengan total sampling sebanyak 38 orang di SMP negeri 2 Pagentan. Instrumen penelitian yang digunakan dalam penelitian ini telah dilakukan uji validitas dan reliabilitas.

Hasil penelitian ada hubungan antara obesitas dengan harga diri pada remaja dengan $p$ value 0,031 . Disarankan tenaga kesehatan memberikan pendidikan kesehatan tentang harga diri bagi remaja yang memiliki obesitas. Remaja diharapkan mengkonsumsi makanan sehat dan gizi yang seimbang serta melakukan aktifitas fisik secara rutin.
\end{abstract}

Kata Kunci: obesitas; harga diri; remaja

\section{Pendahuluan}

Remaja sebagai masa transisi yang ditandai perubahan fisik, emosi dan psikis. Saat remaja terjadi proses pematangan organ reproduksi manusia atau terjadi masa 
pubertas. Remaja mengalami periode perpindahan dari masa anak ke dewasa. Perubahan fisik mengalami perubahan. Gambaran diri tentang perubahan bentuk tubuh dapat mempengaruhi harga diri (Erikson dalam Potter \& Perry, 2009).

Remaja di Indonesia banyak yang mengalami obesitas atau kegemukan. Masyarakat Indonesia yang mengalami kegemukan jumlahnya semakin meningkat saat ini (Harjatmo et al., 2017). Kejadian obesitas atau kegemukan di Indonesia mencapai angka $21,8 \%$ pada tahun 2018 (Kementerian Kesehatan RI, 2018). Obesitas memiliki dampak yang kurang baik bagi kesehatan dan psikologi remaja. Salah satu dampak buruk obesitas bagi kesehatan adalah risiko mengalami penyakit kronis antara lain penyakit jantung, diabetes mellitus dan kanker (Nugroho \& Sudirman, 2020).

Pengaruh obesitas dapat menyebabkan hal negatif terutama dampak psikologis kepada remaja seperti gangguan harga diri. Gangguan harga diri dengan adanya perasaan negatif pada diri sendiri, tidak berharga, tidak percaya diri dan putus asa (Taurisiawati \& Husnina, 2019).

Harga diri sebagai cara pandang seseorang terhadap diri sendiri sedangkan ideal diri merupakan perilaku yang sesuai dengan keinginannya. Tingkat harga diri yang rendah terjadi karena ada perbedaan konsep diri dengan ideal diri yang tinggi. Harga diri yang tinggi mempengaruhi peran dan aktivitas sosial dalam interaksi sosial. Kebutuhan harga diri tidak dapat disadari, sehingga akan mengakibatkan frustrasi, harga diri yang rendah, merasa kurang berharga maupun tidak berguna di masyarakat (Tasnin et al., 2020).

Remaja yang mengalami kegemukan atau obesitas akan mempempengaruhi harga diri. Kebutuhan dasar menurut Maslow dikutip oleh Muazaroh \& Subaidi (2019) menyatakan harga diri merupakan kebutuhan yang dianggap kuat. Kebutuhan untuk dihargai sangat penting sehingga akan berdampak pada psikologis seseorang berupa rasa percaya diri, mempunyai nilai terhadap diri yang tinggi dan kuat.

Menurut Nelwan (2019) dikutip oleh (Widiastuti et al., 2021), Remaja adalah individu, baik perempuan maupun laki-laki, umur antara 10 dan 19 tahun. Pada masa remaja, individu akan mengalami kedewasaan perubahan yang mencolok baik secara fisik maupun psikis.

Menurut Nardina et al. (2021), menyatakan bahwa siswa-siswi SMP termasuk anak remaja. Kebiasaan makan pada orang remaja hampir sama dengan pola makan orang dewasa. Keinginan nafsu makan yang besar pada masa remaja harus dimbangi dengan makanan yang bergizi dan seimbang. Kebutuhan gizi yang sehat dan seimbang sangat dibutuhkan untuk mencegah kegemukan.

Perubahan fisik yang terjadi diantaranya penambahan berat badan. Berat badan yang ideal sangat diharapkan oleh remaja untuk mempertahankan harga diri. Dampak obesitas akan mempengaruhi harga diri remaja. Perubahan fisik seperti obesitas akan mempengaruhi psikologis pada remaja.

Permasalahan harga diri secara terus-menerus dapat terjadi pada remaja putri saat ada peningkatan berat badan. Penambahan lemak tubuh, pertumbuhan tinggi badan, pembesaran pada payudara berkaitan dalam proses kematangan tubuh remaja putri. Remaja merasa kurang nyaman dengan penambahan berat badan yang terlalu cepat, sebagian besar remaja menginginkan penampilan sama seperti teman sebaya dengan berat badan ideal (Proverawati, 2010).

Perasaan kurang percaya diri sering dialami oleh remaja yang obesitas. Remaja yang mengalami obesitas biasanya akan menjadi kurang aktif, merasa tertekan dan tidak terlibat dalam kegiatan dengan teman sebaya. Pengaruh yang tidak baik terhadap kesehatan fisik dan mental individu untuk kehidupan selanjutnya, seperti kolesterol tinggi, hipertensi, diabetes mellitus, penyakit jantung, pernapasan terganggu, persendian yang tidak nyaman dan kanker yang menyebabkan penurunan harapan hidup (Nugroho \& Sudirman, 2020).

Hasil wawancara dengan siswa-siswi SMP Negeri 2 Pagentan Kabupaten Banjarnegara yang mengalami obesitas menjelaskan kurang percaya diri ketika bersama-sama interaksi dengan rekan seusianya, menyatakan kurang percaya diri saat akan mengungkapkan perasaan mempunyai tubuh yang gemuk. Siswa-siswi 
yang mengalami tubuh dengan penumpukan lemak yang berlebihan cenderung tidak mau berkumpul dan lebih senang berinteraksi dengan siswi yang mempunyai bentuk tubuh yang sama dengan dirinya. Berdasarkan penelusuran publikasi belum ditemukan penelitian obesitas dan harga diri siswa SMP, sehingga perlu dilakukan untuk meningkatkan referensi pengelolaan kesehatan pada remaja dan anak sekolah

\section{Metode Penelitian}

Jenis penelitian ini menggunakan survey analitik dengan menggali bagaimana dan mengapa peristiwa itu terjadi. Rancangan penelitian ini dengan metode cross sectional.

Populasi penelitian ini yaitu siswa-siswi SMP Negeri 2 Pagentan Kabupaten Banjarnegara yang mengalami obesitas sejumlah 38 orang dengan rentang usia 13-16 tahun. Dalam penelitian ini menggunakan teknik total sampling, yaitu siswa-siswi SMP Negeri 2 Pagentan yang mengalami obesitas sejumlah 38 responden.

Pada penelitian ini variabel bebas yaitu obesitas. Pengukuran obesitas mengukur berat badan dan tinggi badan responden dengan Indeks Massa Tubuh (IMT) menggunakan rumus $\frac{\mathrm{BE}(\mathrm{kg})}{\mathrm{TB}(\mathrm{m})^{2}}$.

Variabel terikat penelitian ini yaitu harga diri remaja. Pengumpulan data harga diri menggunakan kuesioner dari Arpan (2012) yang telah dilakukan uji validitas dan reliabilitas. Pernyataan dalam kuesioner berjumlah 29 poin dengan pilihan jawaban terdiri dari : STS (Sangat Tidak Sesuai), TS (Tidak Sesuai), S (Sesuai), SS (Sangat Sesuai). Bobot nilai pada setiap pilihan berada pada rentang 1-4. Hasil pengumpulan data selanjutnyadilakukan analisis data secara univariat dan bivariat.

\section{Hasil dan Pembahasan}

Responden dalam penelitian ini adalah siswa-siswi SMP Negeri 2 Pagentan yang berdasarkan tingkat obesitas dan harga diri. Data Tabel 1, menunjukkan sebagian besar siswa-siswi mengalami obesitas tipe I sebanyak $71,1 \%$ dibandingkan obesitas tipe II (28,9\%). Hasil penelitian didapatkan persentase obesitas I lebih besar dari obesitas II dengan rentang usia 13-16 tahun dikarenakan karena responden pada masa masa pertumbuhan, faktor fisiologis tubuh seseorang cenderung sebagai penyebab obesitas yang terjadi pada masa remaja.

Tabel 1. Distribusi Remaja berdasarkan Kategori Obesitas

\begin{tabular}{lcc}
\hline \multicolumn{1}{c}{ Obesitas } & $\begin{array}{c}\text { Frekuensi } \\
(\mathrm{f})\end{array}$ & $\begin{array}{c}\text { Persentas } \\
(\%)\end{array}$ \\
\hline $\mathrm{I}\left(\geq 25-29,9 \mathrm{~kg} / \mathrm{m}^{2}\right)$ & 27 & 71,1 \\
$\mathrm{II}\left(\geq 30 \mathrm{~kg} / \mathrm{m}^{2}\right)$ & 11 & 28,9 \\
\hline Total & 38 & 100 \\
\hline
\end{tabular}

Menurut WHO untuk mengetahui seseorang mengalami obesitas dengan menggunakan Indeks Massa Tubuh (IMT) atau Body Mass Index (BMI). Indeks massa tubuh merupakan salah satu pengukuran membandingkan antara berat badan dengan tinggi badan. indeks massa tubuh yaitu rasio yang dinyatakan dengan rumus IMT = berat badan $(\mathrm{kg}) /$ tinggi badan $(\mathrm{m})^{2}$. WHO menyatakan obesitas I apabila seseorang memiliki IMT $\geq 25-29,9 \mathrm{~kg} / \mathrm{m}^{2}$ dan obesitas II memiliki IMT $\geq 30 \mathrm{~kg} / \mathrm{m}^{2}$.

Hasil penelitian ini siswa-siswi mengalami obesitas I dengan IMT $\geq 25-29,9$ $\mathrm{kg} / \mathrm{m}^{2}$. Hal ini sesuai pendapat Proverawati (2010) bahwa penyebab obesitas yang mendasar pada masa remaja terjadi saat tubuh memperoleh kalori lebih banyak, namun yang digunakan hanya sedikit. Kalori selanjutya bertambah banyak dalam tubuh dan menjadi cadangan lemak. Kegemukan pada masa usia remaja dipengaruhi beberapa faktor diantaranya gerakan fisik yang kurang aktif sehingga penggunaan lemak menjadi sedikit kalori serta mengkonsumsi makanan dengan tinggienergi terutama makanan yang siap disajikan atau fast food.

Kelebihan asupan gizi mengakibatkan obesitas. Kelebihan energi yang dikonsumsi akan disimpan di bawah kulit sebagai cadangan energi tubuh dalam bentuk lemak. Kegemukan sebagai faktor risiko terjadinya berbagai penyakit penurunan fungsi tubuh seperti tekanan darah tinggi, diabetes mellitus, penyakit jantung koroner, penyakit hati, penyakit kantong empedu dan kanker (Harjatmo et al., 2017). 
Obesitas pada remaja dapat berlanjut terus hingga tahap dewasa. Obesitas disebabkan kebiasaan remaja cenderung memilih makanan yang tidak sehat dan cenderung fast food. Faktor perilaku seperti mengkonsumsi buah dan sayur sangat baik untuk kesehatan pada remaja. Makanan ini dapat digunakan sebagai pengganti makanan berisiko seperti makan makanan tinggi gula, makanan cepat saji, makanan kolesterol dan makanan berisiko lainnya (Nugroho et al., 2020).

Tabel 2. Distribusi Responden berdasarkan Kategori Harga Diri

\begin{tabular}{lcc}
\hline \multicolumn{1}{c}{ Harga Diri } & $\begin{array}{c}\text { Frekuensi } \\
(\mathrm{f})\end{array}$ & $\begin{array}{c}\text { Persentase } \\
(\%)\end{array}$ \\
\hline Tinggi & 0 & 0 \\
Sedang & 24 & 63,2 \\
Rendah & 14 & 36,8 \\
\hline \multicolumn{1}{c}{ Total } & 38 & 100 \\
\hline
\end{tabular}

Data Tabel 2. menyebutkan siswa-siswi yang mengalami obesitas memiliki harga diri rendah sebanyak $36,8 \%$. Kondisi fisik dengan obesitas menjadikan sesorang memiliki harga diri rendah.

Remaja yang mengalami kelebihan berat badan dengan harga diri rendah sebanyak 43,3\%. Obesitas dapat mengakibatkan masalah rasa percaya diri remaja. Harga diri remaja merupakan suatu hal yang penting dalam pergaulan di masyarakat (Moha et al., 2017).

Obesitas mempunyai dampak mengganggu psikis pada remaja, yaitu sering merasa kurang percaya diri. Remaja yang mengalami kelebihan lemak dalam tubuh, biasanya akan kurang aktif dan merasa sedih serta depresi. Jarang tidak melibatkan diri pada kegiatan yang dilakukan oleh teman sebaya (Nugroho \& Sudirman, 2020).

Kegemukan pada masa remaja awal dapat menyebabkan harga diri rendah. Perubahan fisik pada masa pubertas membuat remaja putri selalu memperhatikan dirinya. Seseorang dengan tubuh yang gemuk akan merasa malu dengan kelebihan berat badan dan merasa tidak puas dengan dirinya (Taurisiawati \& Husnina, 2019).

Penelitian ini menggunakan uji korelasi Kendall's Tau, untuk mengetahui hubungan obesitas dengan harga diri dapat dilihat pada tabel 3.

Tabel 3. Hubungan Obesitas dengan

Harga Diri

\begin{tabular}{ccccccccc}
\hline $\begin{array}{c}\text { Harga } \\
\text { Diri }\end{array}$ & \multicolumn{3}{c}{ Obesitas } & & Total & $\begin{array}{c}\text { P-Va } \\
\text { lue }\end{array}$ \\
\hline & \multicolumn{1}{c}{ I } & \multicolumn{2}{c}{ II } & & & \\
& $f$ & $\%$ & $f$ & $\%$ & $f$ & $\%$ & \\
Tinggi & 0 & 0 & 0 & 0 & 0 & 0 & 0,031 \\
Sedang & 20 & 53 & 4 & 11 & 24 & 64 & \\
Rendah & 7 & 18 & 7 & 18 & 14 & 36 & \\
\hline Total & 27 & 71 & 11 & 29 & 38 & 100 & \\
\hline
\end{tabular}

Tabel 3. menunjukkan bahwa terdapat hubungan antara obesitas dengan harga diri siswa-siswi SMP Negeri 2 Pagentan dengan $p$-value 0,031 .

Penelitian ini sesuai dengan Taurisiawati \& Husnina (2019), bahwa terdapat pengaruh obesitas dengan harga diri remaja. Remaja putri yang obesitas cenderung mengalami tingkat harga diri yang rendah ( $p$ value 0,000 ). Tingkat harga diri yang rendah dapat menyebabkan gangguan psikologis seperti school bullying, sedih, depresi, dan rasa rendah diri pada remaja.

Angka kejadian obesitas pada anak usia sekolah dapat ditekan dan risiko munculnya gangguan akibat obesitas pada usia dini itu dapat dicegah. Faktor psikologi seperti depresi dan stres memiliki hubungan yang bermakna dengan status gizi pada remaja di Pekanbaru (Masdar et al., 2016).

Penelitian lain menunjukkan ada hubungan antara obesitas dengan harga diri (self-esteem) pada remaja putri diperoleh nilai $r h o=0,617$, nilai $p$-value 0,000 . Remaja diharapkan untuk selalu mengatur frekuensi makan dan jenis makanan sehat, melakukan kegiatan aktivitas fisik supaya tidak terjadi obesitas dan mencegah harga diri yang rendah pada remaja (Wulandari et al., 2018).

Hasil penelitian yang sama terdapat hubungan yang bermakna antara obesitas terhadap harga diri pada remaja (nilai $\rho=$ 0,023). Obesitas sebagai bentuk fisik dengan penampilan kelebihan berat badan sehingga dapat mempengaruhi harga diri dan rasa percaya diri seseorang. Obesitas dapat menimbulkan beberapa 
ketidakmampuan fisik yang dapat menyebabkan rasa kurang percaya diri (Moha et al., 2017).

Berbeda dengan hasil penelitian Kurdanti et al. (2015), tidak terdapat hubungan obesitas dengan harga diri pada remaja. Beberapa faktor yang mempengaruhi perkembangan individu yang positif dengan merasa dimiliki, merasa dihargai, dan diterima oleh keluarga serta lingkungannya dapat membentuk harga diri yang positif terhadap remaja. Memiliki orang tua yang selalu memberikan motivasi yang positif terhadap remaja dapat membangun rasa percaya diri yang tinggi pada remaja.

Keterbatasan penelitian hanya meneliti pengaruh obesitas terhadap harga diri remaja. Masih ada hal-hal yang dapat menjadi penyebab harga diri remaja seperti cara orang tua mengasuh putra-putrinya, hasil akademik di sekolah maupun pengaruh lingkungan.

\section{Kesimpulan}

Sebagian besar siswa-siswi mengalami obesitas tipe I, terdapat hubungan yang bermakna antara obesitas dengan harga diri pada siswa-siswi SMP Negeri 2 Pagentan dengan $p$-value 0,03. Disarankan bagi tenaga kesehatan memberikan pendidikan kesehatan tentang pencegahan obesitas. Remaja diharapkan mengatur frekuensi makan sehari-hari, makanan yang sehat dan seimbang serta melakukan aktifitas fisik secara rutin.

\section{Ucapan Terima Kasih}

Ucapan terima kasih kami disampaikan kepada responden dan pihak-pihak yang membantu pelaksanaan penelitian ini.

\section{Daftar Pustaka}

Arpan. (2012). Studi komparatif harga diri berdasarkan pola asuh orang tua pada remaja di SMK PIRI 3 Yogyakarta. STIKES 'Aisyiyah Yogyakarta.

Harjatmo, T. P., Par'i, H. M., \& Wiyono, S. (2017). Buku Ajar Gizi Penilaian Status Gizi (Pertama). Pusat Pendidikan SDM
Kesehatan Badan PPSDM Kesehatan.

Kementerian Kesehatan RI. (2018). Hasil Utama Riskesdas 2018. Kementerian Kesehatan Badan Penelitian dan Pengembangan Kesehatan.

Kurdanti, W., Suryani, I., Syamsiatun, N. H., Siwi, L. P., Adityanti, M. M., Mustikaningsih, D., \& Sholihah, K. I. (2015). Faktor-faktor yang Mempengaruhi Kejadian Obesitas pada Remaja. Jurnal Gizi Klinik Indonesia, 11(4), 179. https://doi.org/10.22146/ijcn.22900

Masdar, H., Saputri, P. A., Rosdiana, D., Chandra, F., \& Darmawi, D. (2016). Depresi, ansietas dan stres serta hubungannya dengan obesitas pada remaja. Jurnal Gizi Klinik Indonesia, 12(4),

https://doi.org/10.22146/ijcn.23021

Moha, M. K., Bidjuni, H., \& Lolong, J. (2017). Hubungan Obesitas Dengan Harga Diri Pada Remaja Di SMA Negeri 1 Limboto Kecamatan Limboto Kabupaten Gorontalo. E-Journal Keperawatan ( $e-K p), 5(1)$.

Muazaroh, S., \& Subaidi. (2019). Kebutuhan Manusia dalam Pemikiran Abraham Maslow. Al-Mazahib, 7(1), 17-33. ejournal.uin-suka.ac.id , almazahib , article > download

Nardina, E. A., Astuti, E. D., Hutomo, C. S., Winarsih, Prihartini, S. D., Azizah, N., Sumiyati, Mahmud, A., Sari, C. R., Simanjuntak, R. R., Revika, E., Megasari, A. L., Pujian, S., Wijayanti, I., Sebtalesy, C. Y., Saragih, H. S., \& Argaheni, N. B. (2021). Gizi Reproduksi (R. Watrianthos (ed.); 1st ed., Vol. 1). Yayasan Kita Menulis.

Nugroho, P. S., \& Sudirman, S. (2020). Analisis Risiko Kegemukan Pada Remaja dan Dewasa Muda. Jurnal Dunia Kesmas, 9(4), 537-544. https://doi.org/10.33024/jdk.v9i4.3238

Nugroho, P. S., Wijayanti, A. C., Sunarti, S., Suprayitno, \& Sudirman. (2020). Obesity and its risk factors among adolescent in Indonesia. Malaysian Journal of Medicine and Health Sciences, 16(2), 173-179.

Potter, P. A., \& Perry, A. G. (2009). Buku Ajar Fundamental Keperawatan (7th ed.). EGC. 
Proverawati, A. (2010). Obesitas dan Gangguan Perilaku Makan pada Remaja (1st ed.). Nuha Medika.

Tasnin, Widiastuti, A., Kurniasih, H., Purwanti, K. D., Hastuti, P., Hapsari, W., Sitorus, S., Sumiyati, Hutabarat, J., \& Wahyuni. (2020). Keterampilan Dasar Kebidanan Teori \& Praktik (J. Simarmata (ed.); 1st ed., Vol. 1). Yayasan Kita Menulis.

Taurisiawati, D. T., \& Husnina, L. (2019). Obesitas Dengan Harga Diri pada Remaja Putri Kelas X SMK YP 17 Kediri. Jurnal Gizi KH, 2(1), 1-7.

Widiastuti, A., Azizah, N., Indryani, Ismawati, Tahir, A., Haslan, H., Kurniasih, H.,
Hutomo, C. S., Sumiyati, \& Bayu, N. (2021). Epidemiologi Kesehatan Reproduksi (R. Watrianthos (ed.); 1st ed., Vol. 1). Yayasan Kita Menulis.

Wulandari, P., Arifianto, A., \& Aini, N. (2018). Hubungan Obesitas dengan Harga Diri (self-esteem)pada Remaja Putri SMA Negeri 13 Semarang. Jurnal Keperawatan Soedirman, 11(2), 81. https://doi.org/10.20884/1.jks.2016.11.2 .650 